\title{
Features of operation of drainage systems in the area of drainage in modern conditions (on an example of the Western region of Volyn obl.)
}

\author{
Mozol N. ${ }^{1}$, Voropai H. ${ }^{2}$ \\ 1, 2Institute of Water Problems and Land Reclamation of NAAS, 37 Vasylkivska Str., Kyiv, 03022, \\ Ukraine \\ e-mail: ${ }^{1}$ moznaz@ukr.net, ${ }^{2}$ voropaig@ukr.net \\ ORCID: ${ }^{1}$ 0000-0001-7495-4702, ${ }^{2} 0000-0002-5004-0727$
}

Goal. To analyze the peculiarities of drainage systems in Western Polissia of Ukraine; to formulate on the basis of the analysis of the research the main activities in order to improve the efficiency of inter-farm and on-farm systems in humid zone. Methods. Economical-statistical, formalized reflection. Results. Growth is fixed in government funding and contracts for the reconstruction and repair of the network irrigation and drainage systems in the Volyn obl. (Ratniv Interdistrict management of water economy) for the period $2010-2018$. The majority of the funding (85\%) was focused on the maintenance and operation of systems. $15 \%$ of all funds were allocated for capital repairs. Due to the perfect operation of drainage systems of on-farm and inter-farm value during 2018-2019 only for certain low areas of the Pripyat river the level of water raised on $0.3-0.4 \mathrm{~m}$ above the zero position. At the same time, the excess of marks of flooding of riverine settlements was $0.1-0.2 \mathrm{~m}$ and did not harm agricultural land. Periods of removal of excess water was $0.5-2$ days. For comparison, the period of snowmelt and spring rains of 2009 was characterized by significant rise of groundwater level, the water level in the Pripyat river raised above 1.2 $\mathrm{m}$, the removal of excess water from flooded areas lasted about 1 month. Conclusions. A positive example of maintenance of drainage network in the Volyn obl., the interaction of land and operational services, qualified repair and maintenance is the key to the sustainable functioning of drainage systems and effective use of reclaimed agricultural lands, protection of settlements from the harmful effects of water.

Key words: agro landscape, land reclamation, excessive water, modernization, land users. DOI: https://doi.org/10.31073/agrovisnyk202002-12

Conducting agricultural production on the drained lands of the humid zone is characterized by imperfection of the system of water resources management and land reclamation. The lack of regulation of the mechanisms of utilization of domestic land reclamation systems makes it impossible to raise funds for the implementation of measures for modernization and reconstruction of the existing infrastructure of water management areas [1].

For a long period 2000-2018 the ecological reclamation and technical condition of the drainage drainage network is characterized as satisfactory or unsatisfactory [1]. At the same time, only $35 \%$ of the domestic network are in working (working) condition and can perform their functions in the project mode, on the intermunicipal network - about $85 \%$.

After the reform of the water management system of Ukraine in the 2000s, balancing holders of domestic land reclamation systems became local councils (more often rural ones), state agricultural enterprises and private agricultural companies. The scope of their responsibility includes the operation of the system to ensure optimal water-air regime of reclaimed soils, identify sources of funding, coordinate actions with the advisory services of the State Agency of Water Resources of Ukraine (hereinafter the State Agency for Water Resources) [2]. It should be noted that the share of reclaimed land in the use of enterprises decreased from $99 \%$ in 1990 to $33.5 \%$ in 2018 . It is clear that due to the large number of land users of the reclaimed territories (more than 900 thousand) and the existing drainage network, the operation of domestic channels was complicated and structures, the control of the technical condition, ecological-ameliorative monitoring, etc. has been weakened.

Purpose of research. Using the example of a typical administrative-territorial unit in the western part of the Polissya of Ukraine, to analyze the peculiarities of the operation of the existing drainage systems, to formulate the basic measures for increasing the efficiency of their functioning.

Research Methods. Economic and statistical - to determine the current state of operation of drainage systems, features of their functioning and efficiency; formalized display - to identify the overall structure of the drainage system management as a complex of hydraulic structures.

Research results. According to the State Statistics Service of Ukraine and the State Resources' reporting materials, the share of the area serviced by drainage systems in the total area of the farmland of Ratnivsky Interregional Water Management Department (hereinafter RMWG) is 77\% or 132.3 thousand ha [2]. Four administrative districts of Polissya zone of Volyn region - Ratnovsky, Starovyzhivsky, Lyubomlsky 
and Shatsky are included in the service area of irrigation systems of the Regional Inspectorate of Regional Development. As of January 1, 2019 there are 62 irrigation drainage systems in the area. On the area of 76.2 thousand hectares bilateral regulation of the water-air regime of soils is applied, on 19.3 thousand hectares polder systems are functioning. The length of the open drainage network is $5425.1 \mathrm{~km}$, the closed one is $28241.4 \mathrm{~km}$, ie the ratio of open / closed network is 1: $5(\mathrm{~km})$.

The largest system in the Ratnivsky MUVG service area is the Pripyat drainage system with an area of 25.9 thousand hectares, the water intake is the Pripyat River. Also, the large reclamation systems of the area can be attributed to the Turkish, Kortelisk, Kyziv, and Neretva systems (Table).

\section{Characteristics of the largest land reclamation systems of RMWG}

\begin{tabular}{|c|c|c|c|c|}
\hline $\begin{array}{c}\text { Name of the } \\
\text { reclamation system }\end{array}$ & Water receiver & $\begin{array}{c}\text { The drained } \\
\text { area, } \\
\text { thousand } \\
\text { hectares }\end{array}$ & $\begin{array}{c}\text { Closed } \\
\text { drainage } \\
\text { network, } \\
\mathrm{km}\end{array}$ & $\begin{array}{c}\text { Open drainage } \\
\text { network, } \\
\mathrm{km}\end{array}$ \\
\hline Pripyatskaya & Pripyat & 25,9 & 4663 & 1323 \\
\hline Upper Pripyat & Pripyat & 25.1 & 4514 & 1728 \\
\hline Turs'ka & Turs'kyy MK & 9,1 & 1777 & 461 \\
\hline Kortelis'ka & Lake Lyubove & 4,8 & 551 & 299 \\
\hline Kyzivs'ka & Kizivka River & 4,6 & 1908 & 177 \\
\hline Neretvivs'ka & Zah. Bug River & 6,0 & 1434 & 275 \\
\hline Hapens'ka & Zah. Bug River & 5,2 & 1589 & 262 \\
\hline
\end{tabular}

The peculiarity of the Polissya drainage systems is that most of them are occupied by the inter-economic network, in the research area $35 \%$ of the backbone and the wired network is of inter-economic importance, the remaining $65 \%$ - inter-economic. All available closed drainage network is on the balance of local selfgovernment bodies and is of internal economic importance.

Qualified technical operation and maintenance of the design parameters of all components of the engineering infrastructure of the land reclamation system is a guarantee of the efficiency of agricultural production and protection of settlements from natural and climatic disasters. Due to the inability of operational regulation of the water-air regime of reclaimed lands during floods, settlements and agricultural lands are flooded. According to the inventory made by the State Resources in 2011, 56.9 thousand ha are used for the area of 103.3 thousand hectares of the area of RMWGG area under the RMUHG activity area. Areas overgrown with shrubs and woodland occupy 29.1 thousand hectares or $22 \%$ of the total reclaimed area. In comparison with the previous years [2], the areas of land not used in agricultural production in the period $2010-2018$ decreased by $5-7 \%$.

On the basis of the conducted studies of the functioning of the land reclamation systems [3] and the analysis of the reporting materials of the relevant departments, the following groups of factors are identified which have a negative impact on the agricultural use of the reclaimed territories:

- $37,4 \%$ of the territory - social and organizational reasons (reform of agricultural enterprises, changes of owners and forms of management, changes in the structure of crop rotation or purpose of land, etc.);

- $35.1 \%$ - unsatisfactory technical condition of the internal drainage network;

- $16.2 \%$ - unsatisfactory land reclamation status;

- $11.3 \%$ - other reasons.

The peak of construction of irrigation drainage systems in the Polesie region is in the 60-80s of the last century. It was at this time that considerable funds were invested in land reclamation. For stable and efficient functioning, built systems still require significant investment to complete the entire range of work to ensure their efficiency.

It is clear that reforming the agrarian sector and all related organizational nuances require a lot of time and teamwork not only by specialists of the water management complex, but also by specialists of many related areas of the country's economy. Therefore, at this stage the main attention should be paid to the measures, which in the short term will allow to ensure the effective functioning of the land reclamation systems [4]. Such measures should include overhaul and modernization, restoration of design parameters of the drainage network of domestic importance.

Financing of works related to the operation and repair of reclamation systems or individual objects of engineering infrastructure, monitoring and inventory of reclaimed land, inventory and certification of reclamation systems should be done at the expense of state and local budgets and from other sources not prohibited by law [1 ]. The main share in the structure of budget financing of land reclamation works falls on the inter-economic network. A significant increase in the amount of financing for the overhaul of the inter-economic land reclamation network has been observed since 2011 due to the allocation of funds by the Cabinet of Ministers of Ukraine in accordance with the decree "On allocation of funds for the implementation of measures aimed at preventing emergencies in the Volyn region".

The total carrying value of the reclamation funds of the studied area is UAH 347.9 million, including the inter-economic network in the RMWG service area - UAH 120.3 million. In order to ensure the efficient functioning of inter-farm land reclamation systems, repair and other works worth over UAH 2.2 million were 
performed only in 2018. In total, $31.0 \mathrm{~km}$ of canals and dams were cleared on the open inter-farm network, mowing was done - $1181.2 \mathrm{~km}$, shrubs were cut down - $268.4 \mathrm{~km}, 241$ hydraulic structures (GTS) were repaired or modernized. On the domestic economic network, based on the concluded agreements with landowners, cleared of sediment more than $5.0 \mathrm{~km}$ of canals, 124 GTS were repaired. In total, repair works worth over UAH 0.31 million were completed, including capital projects - UAH 0.24 million. and UAH 0.07 million. - current.

In the period 2010-2018, in Volyn region and, in particular, in the area of RMWG activities, there is an increase in the volume of state funding for reconstruction and repair of reclamation systems, especially inter-economic network (Fig. 1). Most of the funding (up to $85 \%$ ) is directed to the maintenance and operation of systems, up to $15 \%$ of all funds is allocated for major repairs.

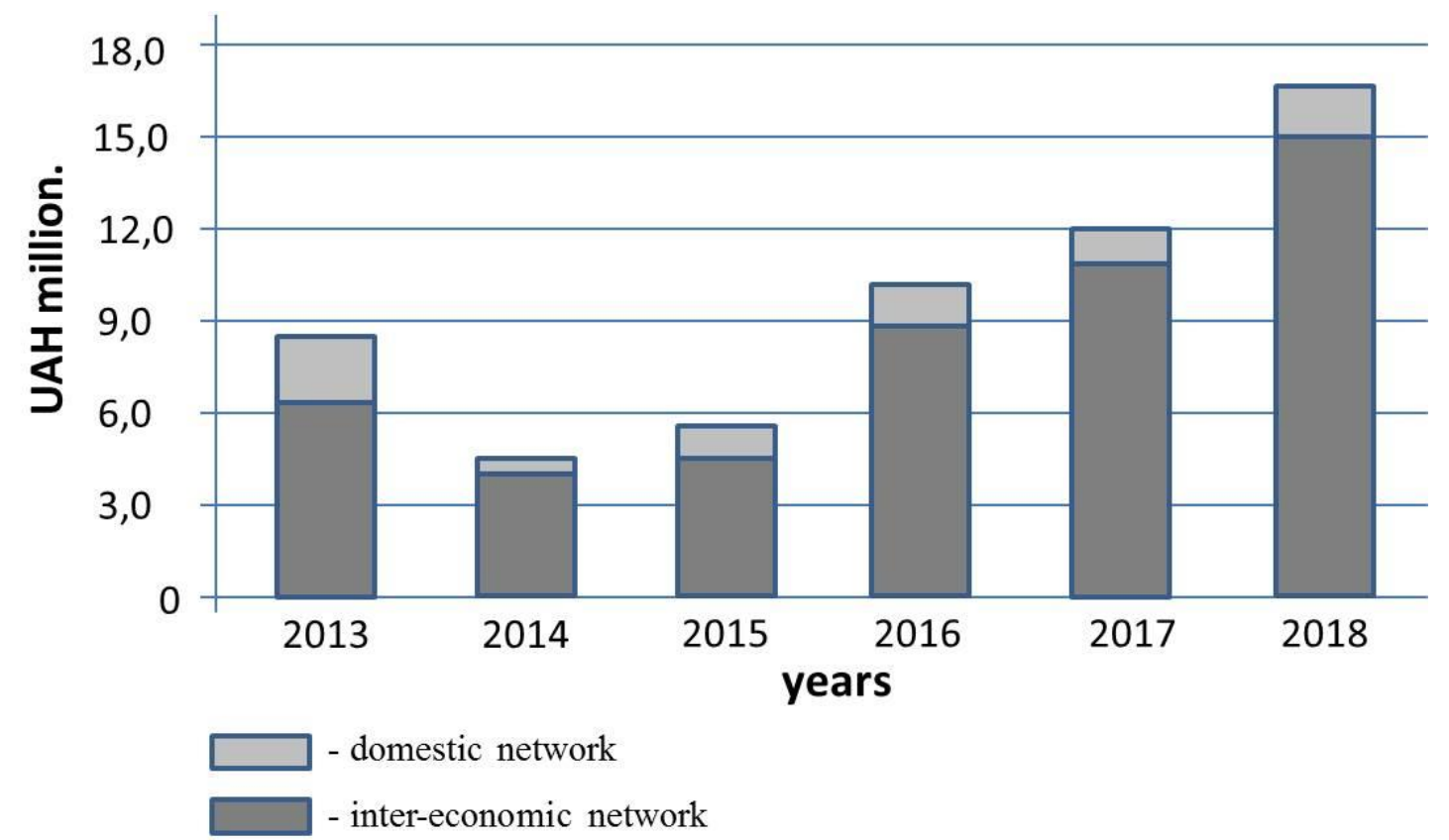

Fig. 1. Volume of execution of repair works on reclamation systems, subordinated to RMWG

The conducted analysis of the compliance of the state financing of amelioration measures and actually performed works on the inter-economic and internal economic systems of the Regional Inspectorate of Regional Development of Internal Affairs shows that the amount of repair work over their budget financing is exceeded [2]. Thus, in 2018, about 0.31 million hryvnias were concluded for the repair of land reclamation systems of domestic importance, which is $45 \%$ more than in the previous year. Basically, work is being done to regulate the water-air regime of the surrounding territories by clearing open channels from shrubs, dredging, repair of the GTS, etc. For the period 2010-2018, the volumes of these works are growing: from UAH 0.01 million. in 2010 to UAH 0.31 million. in 2018 In total, over the last decade, over 100.0 hectares of area, work has been carried out to restore the design parameters of domestic land reclamation systems, with about $50.0 \mathrm{~km}$ of canals cleared and more than 750 GTS being repaired.

Based on numerous scientific researches [6-9] and the current experience of operating the $\mathrm{CU}$, the best option for investing in land reclamation is the reconstruction of reclamation systems, which is economically advantageous. Costs for its implementation are $45-55 \%$ less than for new construction, which allows to increase the productivity of land up to $60 \%$. At present, the planned indicators of the state budget for financing the "operation of the state water management complex and water resources management". Do not allow to expect the complete modernization of reclamation systems. It should be noted that at present the modernization of the $\mathrm{CU}$ in the overall structure of financing is only $5 \%$ (Fig. 2). 


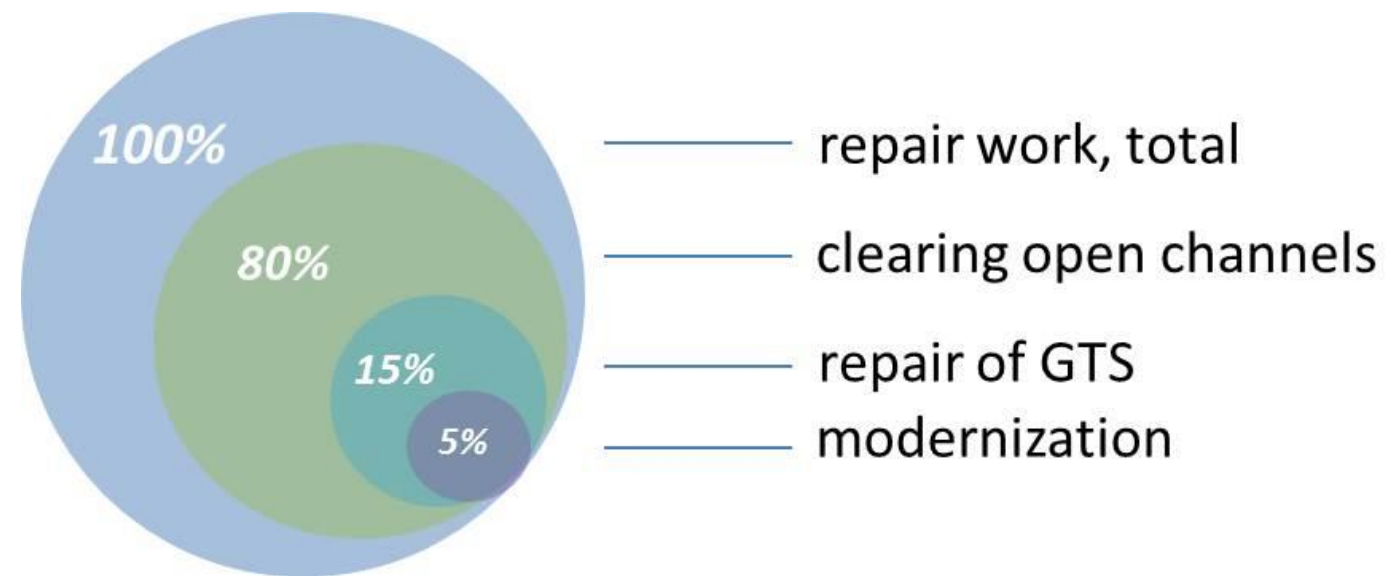

Fig. 2. Structure of budget financing of repair works on reclamation systems

Logistical support and condition of drainage systems are the main factors affecting the potential of agricultural land reclamation. Built in the 60's and 90's, the systems have considerable operational resources and opportunities for modernization. Therefore, the timely and qualified service depends on the efficiency of their work and, accordingly, the profitability of agricultural production in the reclaimed lands of the region.

\section{Conclusions}

The current positive trends in the maintenance of the domestic grid indicate the interest of land users in the stable operation of systems to maintain the optimum water-air regime of reclaimed soils. The analysis of the structure, state of use, technological features of reclamation systems of RMWG allows to formulate basic measures aimed at improving the efficiency of the existing water management complex and water resources management. These measures include:

- inventory of existing systems, their certification;

- financing of works on repair and modernization in accordance with the technical condition of the reclamation network (efficiency of management);

- organization of operation of systems of internal economic value;

- professional support of operational personnel.

\section{References}

1. Pro skhvalennia Stratehii zroshennia ta drenazhu v Ukraini na period do 2030 roku: Rozporiadzhennia Kabinetu Ministriv Ukrainy vid 14 serpnia 2019 r. № 688-r. (2019). [On approval of the Irrigation and Drainage Strategy in Ukraine until 2030: Order of the Cabinet of Ministers of Ukraine dated August 14, 2019. № 688-p]. URL: https://zakon.rada.gov.ua/laws/show/688-2019-\%D1\%80. [In Ukrainian]

2. Zakon Ukrainy "Pro melioratsiiu zemel" vid 01.01.2019 r. № 1389 - XIV (2019). Law of Ukraine "On Land Reclamation" dated 01.01.2019 № 1389-XIV. URL: http://zakon1.rada.gov.ua/laws/show/1389-14. [In Ukrainian]

3. Materialy inventaryzatsii zahalnoderzhavnykh, mizhhospodarskykh i vnutrishnohospodarskykh melioratyvnykh system na 2011 r. (2012). [Materials of the inventory of national, inter-economic and internal economic reclamation systems for 2011]. Kyiv: State Water Service of Ukraine. [In Ukrainian]

4. Silske hospodarstvo Ukrainy. Statystychnyi zbirnyk. Derzhavna sluzhba statystyky Ukrainy (2018). [Statistical collection "Agriculture of Ukraine". State Statistics Service of Ukraine]. Kyiv: Derzhalitinform. [In Ukrainian]

5. Kovalenko, P. I., Chaly, B. I., \& Tyshenko, A. I. (1991). Rekonstruktsiya meliorativnykh sistem [Reconstruction of reclamation systems]. Kyiv: Harvest. [In Russian]

6. Alexievsky, V. E. (1976). Rezhym gruntovykh vod na osushenykh zemliakh Prypiatskoho Polissia Ukrainy. Pytannia melioratsii ta efektyvnoho vykorystannia osushenykh zemel Ukrainskoho Polissia [Groundwater regime in the drained lands of Pripyat Polissya of Ukraine. Issues of land reclamation and efficient use of drained lands of Ukrainian Polissya]. (pp. 53-56). Lviv: Higher School. [In Ukrainian]

7. Pro vydilennia koshtiv dlia zdiisnennia zakhodiv, spriamovanykh na zapobihannia vynyknenniu nadzvychainykh sytuatsii na terytorii Volynskoi oblasti: Rozporiadzhennia Kabinetu Ministriv Ukrainy № 384 $-r$ vid 11.05.2011 r. (2011). [About the view of the cost for healthy visits, direct contact with the public guide to the above situations in the territory of the Volyn region. The order of the Cabinet of Ministers of Ukraine No. 384 - 11.05.2011] URL: http://search.ligazakon.ua/I_doc2.nsf/link1/KR110384.html. [In Ukrainian]

8. Balyuk, S. A., Romashchenko, M. I., \& Truskavetsky, R. S. (Eds.). (2015). Melioratsiia gruntiv (systematyka, perspektyvy, innovatsii) [Soil reclamation (systematics, perspectives, innovations)]. A collective monograph. Kherson: Grin DS. [In Ukrainian] 
9. Ashley, R. M., Walker, L., D’Arcy, B., Wilson, S., Illman, S., Shaffer, P., Woods-Ballard, B., \& Chatfield, P. (2015). UK sustainable drainage systems: past, present and future. Civil Engineering. Proceedings of the Institution of Civil Engineers. ICE Publishing.

10. Markos, H., Shemelies, A., \& Sirak, T. (2019). Performance Evaluation of the Sanko Small Scale Irrigation Scheme at Basketo Special Woreda and SNNPR, Ethiopia. Irrigat Drainage Sys Eng, 8, 2.

11. Hadzal, Ya. M., Stashuk, V. A., \& Rokocinski, A. M. (Eds.) (2018). Melioratsiia ta oblashtuvannia Ukrainskoho Polissia [Reclamation and arrangement of the Ukrainian Polissya]. A collective monograph. (Vol. 2). Kherson: Aldi Plus. [In Ukrainian]

12. Slusar, I. T, Serbeniuk, V. O, \& Gera, O. M. et al. (2016). Urozhainist bahatorichnykh travostoiv na osushuvanykh orhanohennykh gruntakh Lisostepu. Zemlerobstvo [Yields of perennial grasses on drained organogenic soils of the forest-steppe. Agriculture]. (Vol. 1 (90), pp. 92-97). Kyiv: Edelweiss Company. [In Ukrainian]

13. Tarariko, Y. O., Datko, L. V., Stetsyuk, M. G., \& Zosymchuk, M. D. (2016). Transformatsiia osushuvanykh torfovykh gruntiv Zakhidnoho Polissia za dovhotryvaloho silskohospodarskoho vykorystannia [Transformation of Dried Peat Soils of Western Polesie for Long-Term Agricultural Use]. Bulletin of Agrarian Science, 9, 56-60. doi: org/10.31073/agrovisnyk201609-11. [In Ukrainian] 